\title{
Formation and Regeneration of Protoplasts from Pythium PRL 2142
}

\author{
By J. H. SIETSMA* AND W. R. DE BOER \\ Laboratory for Microbiology, University of Amsterdam, Amsterdam, The Netherlands
}

(Received 27 July 1972)

\begin{abstract}
SUMMAR Y
Protoplasts of a strain of Pythium (PRL 2 I42) could be obtained by incubating the mycelium with a combination of helicase and cellulase in the presence of an osmotic stabilizer. This process was inhibited when organic compounds were used as osmotic stabilizers but stimulated by pretreatment of the mycelium with a detergent. The most effective detergent was Triton X I00. Regeneration of protoplasts could be demonstrated in liquid or in solid media, but less than $30 \%$ of the protoplasts were able to grow into new mycelium. In contrast to protoplast formation, regeneration was inhibited by the inorganic salts used as osmotic stabilizer. The results suggest that the hyphal wall of Pythium is covered with a protective layer of lipid material.
\end{abstract}

\section{INTRODUCTION}

The regeneration of fungal protoplasts is of current interest because of the importance of cell-wall formation in morphogenesis. To study this process in Pythium PRL 2I 42 a convenient method is needed to make a large number of protoplasts.

It is possible to make protoplasts of Pythium PRL 2142 with an enzyme system produced by a Streptomyces species, containing cellulase, exo- and endolaminaranase activity (Sietsma, Eveleigh \& Haskins, 1969). The disadvantages of this method are that it takes a long incubation time $(24 \mathrm{~h})$ to get a sizeable number of protoplasts and that the preparation and purification of the enzyme complex is very tedious and laborious. A method has been found which makes large quantities of protoplasts of Pythium within a period of $4 \mathrm{~h}$ by using a combination of commercially available helicase and cellulase. The regeneration of these has been studied.

\section{METHODS}

Organism and growth conditions. Pythium PRL 2I 42 described by Haskins (I963) was grown in shake culture at $28{ }^{\circ} \mathrm{C}$ in a medium containing $(\mathrm{g} / \mathrm{l}): \mathrm{KH}_{2} \mathrm{PO}_{4}, 0.5 ; \mathrm{K}_{2} \mathrm{HPO}_{4}$, $0.5 ; \mathrm{K}_{2} \mathrm{SO}_{4}, 0.5 ; \mathrm{MgCl}_{2} .6 \mathrm{H}_{2} \mathrm{O}, 0.6$; glucose, I0; asparagine, $\mathrm{I} \cdot 2$; and thiamine, $0.00 \mathrm{I}$. Before sterilization the $\mathrm{pH}$ of the medium was adjusted to $6 \cdot 2$, and (cholesterol $(0 \cdot \mathrm{I} \mathrm{g})$ added as a $10 \%(\mathrm{w} / \mathrm{v})$ solution in ethanol. After the culture had grown for a certain time, specified under results, the mycelium was collected by filtration, washed twice with distilled water, and then with an incubation medium containing an osmotic stabilizer dissolved in $0.005 \mathrm{M}$-acetate buffer, $\mathrm{pH} \mathrm{6.2.} \mathrm{The} \mathrm{following} \mathrm{substances} \mathrm{were} \mathrm{used} \mathrm{as} \mathrm{osmotic} \mathrm{stabilizers:}$ $\mathrm{KCl}, 0.4 \mathrm{M} ; \mathrm{NaCl}, 0.4 \mathrm{M} ; \mathrm{NH}_{4} \mathrm{Cl}, 0.4 \mathrm{M} ; \mathrm{MgSO}_{4}, 0.65 \mathrm{M}$; sorbitol, $0.65 \mathrm{M}$; mannitol, $0.65 \mathrm{M}$; sucrose, $0.65 \mathrm{M}$. The mycelium was finally suspended in an incubation medium at a concentration of $30 \mathrm{mg}$ organism $/ \mathrm{ml}$, helicase $(\mathrm{I} \cdot 2 \mathrm{mg} / \mathrm{ml})$ and cellulase $(2 \mathrm{mg} / \mathrm{ml})$ added, and incubated at $30{ }^{\circ} \mathrm{C}$. In some experiments the mycelium was either pretreated or incubated with SH-compounds, chelating agents or detergents as described below.

\footnotetext{
* Present address: Department of Botany, University of Groningen, Haren, The Netherlands.
} 
Enzymes. Helicase (lyophilized snail-gut extract) was obtained from l'Industrie Biologique Française, Gennevilliers, Seine, France; it contained 850 units of laminarinase/mg and 1350 units of cellulase/mg. Cellulase (from Aspergillus niger) was purchased from Nutritional Biochemicals Corporation, Cleveland, Ohio, U.S.A. It contained 90 units of laminaranase $/ \mathrm{mg}$ and 20 units of cellulase $/ \mathrm{mg}$ and was free of lipase activity. Laminarinase, cellulase and lipase activity were estimated as described previously (Eveleigh, Sietsma \& Haskins, I968).

Purification of the protoplasts. After $4 \mathrm{~h}$ of incubation the protoplasts were separated from the rest of the mycelial debris by filtration through glass wool. The filtrate was then centrifuged ( $3000 \mathrm{~g}, 5 \mathrm{~min}$ ) and the precipitated protoplasts washed twice with incubation medium. The protoplasts were finally suspended in the same medium, counted microscopically (with a counting chamber) and diluted with incubation medium to a fixed concentration of protoplasts.

Regeneration of the protoplasts. The regeneration medium consisted of a solution of an osmotic stabilizer plus one or more nutrients $(\mathrm{g} / \mathrm{l}$ : glucose, I ; asparagine, $\mathrm{O} \cdot \mathrm{I}$; yeast extract, $\mathrm{O} \cdot \mathrm{I}$; peptone, $\mathrm{O} \cdot \mathrm{I})$; alternatively the complete growth medium plus osmotic stabilizer was used. Protoplasts $\left(\mathrm{I}^{6} / \mathrm{ml}\right)$ were suspended in the regeneration medium and incubated at $30{ }^{\circ} \mathrm{C}$ (with shaking) in a water bath. Samples were examined periodically by means of phase-contrast microscopy. In some experiments suspensions were incubated for $24 \mathrm{~h}$, centrifuged ( $3000 \mathrm{~g}$, IO $\mathrm{min})$ and the dry weight of the pellet was estimated.

To determine the percentage of protoplasts capable of regeneration, a known number of protoplasts were spread evenly over (or suspended in) a solidified medium in a Petri dish. This medium consisted of the growth medium plus an osmotic stabilizer ( $0.65 \mathrm{M}$-mannitol) and agar $(0.7 \%$ or $2 \%, \mathrm{w} / \mathrm{v})$ or gelatine $(15 \%, \mathrm{w} / \mathrm{v})$. The agar plates were incubated for 3 days at $28^{\circ} \mathrm{C}$ and the gelatine plates for 6 days at $22{ }^{\circ} \mathrm{C}$. Each regenerated protoplast gave a visible colony which was counted.

Regeneration of the hyphal wall was also followed by u.v. fluorescence microscopy. Samples of regenerating protoplasts were centrifuged $(3000 \mathrm{~g}, 5 \mathrm{~min})$ and the pellet suspended in a $0.1 \%(\mathrm{w} / \mathrm{v})$ solution of Calcofluor White MR (kindly supplied by Unilever Research Laboratory, Vlaardingen, The Netherlands) in $0.65 \mathrm{M}$-mannitol. After $20 \mathrm{~min}$ of incubation at room temperature the samples were examined under a Zeiss fluorescence microscope, illuminated with a high-pressure mercury lamp provided with one heat filter $\mathrm{KG}$, one red filter $\mathrm{BG}$, and one exciting filter $\mathrm{UG}_{5}$.

\section{Formation of protoplasts}

RESULTS

With a combination of helicase and cellulase it was possible to make Pythium protoplasts in large quantities in a $4 \mathrm{~h}$ period. Longer incubation times did not increase the total number of protoplasts since lysis was then quite considerable and could almost exceed the rate of formation of new protoplasts. The formation of spherical protoplasts could occur at several points on the hyphae, at intercalary locations as well as at apices of branches. The process of formation and the appearance of the protoplasts was as described previously (Sietsma, Eveleigh, Haskins \& Spencer, 1967).

Several osmotic stabilizers were tested for their effect on protoplast formation. Inorganic salts $\left(\mathrm{MgSO}_{4}, \mathrm{NaCl}, \mathrm{KCl}, \mathrm{NH}_{4} \mathrm{Cl}\right)$ were very favourable when added at a suitable concentration, the best results being obtained with $\mathrm{NaCl}$. The least effective salt was $\mathrm{NH}_{4} \mathrm{Cl}$. Organic stabilizers (sorbitol, mannitol or sucrose) strongly inhibited protoplast formation (Table I). 
Table I. Factors affecting protoplast formation in Pythium

\begin{tabular}{|c|c|c|c|c|c|}
\hline \multirow[b]{2}{*}{$\begin{array}{l}\text { Osmotic stabilizer in the } \\
\text { incubation medium }\end{array}$} & \multirow{2}{*}{$\begin{array}{l}\text { No } \\
\text { pretreatments } \\
\text { No additions }\end{array}$} & \multicolumn{2}{|c|}{ Pretreatments of the mycelium } & \multicolumn{2}{|c|}{$\begin{array}{l}\text { Additions to the incubation } \\
\text { medium }\end{array}$} \\
\hline & & $\begin{array}{l}\text { SH- } \\
\text { compounds* }\end{array}$ & Detergents $\dagger$ & $\begin{array}{l}\text { SH- } \\
\text { compounds* }\end{array}$ & Detergents $\dagger$ \\
\hline $\mathrm{KCl}(0.4 \mathrm{M})$ & +++ & + & ++++ & + & - \\
\hline $\mathrm{NaCl}(0.4 \mathrm{M})$ & +++ & + & ++++ & + & -- \\
\hline $\mathrm{NH}_{4} \mathrm{Cl}(0.4 \mathrm{M})$ & ++ & - & ++++ & + & - \\
\hline $\mathrm{MgSO}_{4}(0.65 \mathrm{M})$ & ++ & + & ++++ & + & - \\
\hline Sorbitol (0.65 M) & + & - & + & - & - \\
\hline Mannitol $(0.65 \mathrm{M})$ & $\longrightarrow$ & $\cdots$ & + & 一 & - \\
\hline Sucrose $(0.65 \mathrm{M})$ & - & - & 一 & 一 & - \\
\hline
\end{tabular}

- No protoplasts after $24 \mathrm{~h} ;+$, few protoplasts after $8 \mathrm{~h} ;++$, numerous protoplasts after $6 \mathrm{~h}$; +++ , numerous protoplasts after $4 \mathrm{~h} ;++++$, numerous protoplasts after $4 \mathrm{~h}$, also with old mycelium.

* SH-compounds used were 2-mercaptoethanol, cysteamine or dithiothreitol in a concentration of $250 \mathrm{~mm}$ during pretreatment, or of $10 \mathrm{~mm}$ when added to the incubation medium.

$\dagger$ Detergents used were deoxycholate, laurylsulphate or Triton XI00 in the same concentrations as the SH-compounds. Addition of detergents to the incubation medium caused lysis of the protoplasts.

Pre-incubation of the mycelium with 2-mercaptoethanol, cysteamine or dithiothreitol (at $250 \mathrm{~mm}$ ), or addition of these substances at a concentration of $10 \mathrm{~mm}$ to the incubation medium, did not affect protoplast formation. Chelating agents, including EDTA (40 mM) and citrate $(50 \mathrm{~mm})$, also were without effect. Neither variation of $\mathrm{pH}$ (between 5 and 7 ) nor temperature (between 22 and $37^{\circ} \mathrm{C}$ ) influenced protoplast formation.

Pre-incubation of the mycelium with a detergent, such as Triton $\mathrm{X}_{100}$, sodium deoxycholate and sodium laurylsulphate (each at $10 \mathrm{~mm}$ ), strongly stimulated protoplast formation, but addition of a detergent to the incubation medium caused lysis of the protoplasts (Table I). The best preparations of protoplasts were obtained by pretreating the mycelium with Triton X100, but with very young mycelia (not older than $24 \mathrm{~h}$ ) this treatment was not necessary for effective protoplast formation.

\section{Regeneration of protoplasts}

Protoplasts regenerate into new mycelium when suspended in a medium with suitable osmotic protection and adequate nutrients. After $3 \mathrm{~h}$ of incubation some protoplasts started to form one or more buds, which grew out to normal hyphae (Fig. I $a, b$ ). Some protoplasts extended to a structure with several swellings before a normal hypha arose (Fig. I $c$ ). However, a great number of protoplasts were still unchanged after $\mathrm{I} 8 \mathrm{~h}$ of incubation. The regeneration process was also followed under the fluorescence microscope after incubating samples with Calcofluor (an optical brightener). This substance adheres specifically to glucans and makes them fluoresce strongly when illuminated with near u.v. light (Preece, I97I). Freshly prepared protoplasts did not fluoresce at all, but after $\mathrm{I} h$ of incubation in the regeneration medium most of them showed a weak fluorescence, that rapidly became brighter on longer incubation. Newly formed buds and hyphae fluoresced very strongly. The tip of the hyphae generally fluoresced more strongly than the rest of the mycelium (Fig. $\mathrm{I} d, e, f)$.

\section{Factors effecting protoplast regeneration}

A protoplast was considered to regenerate when it could grow out to a visible colony on an agar plate when the protoplasts were either suspended in, or evenly spread over, the 

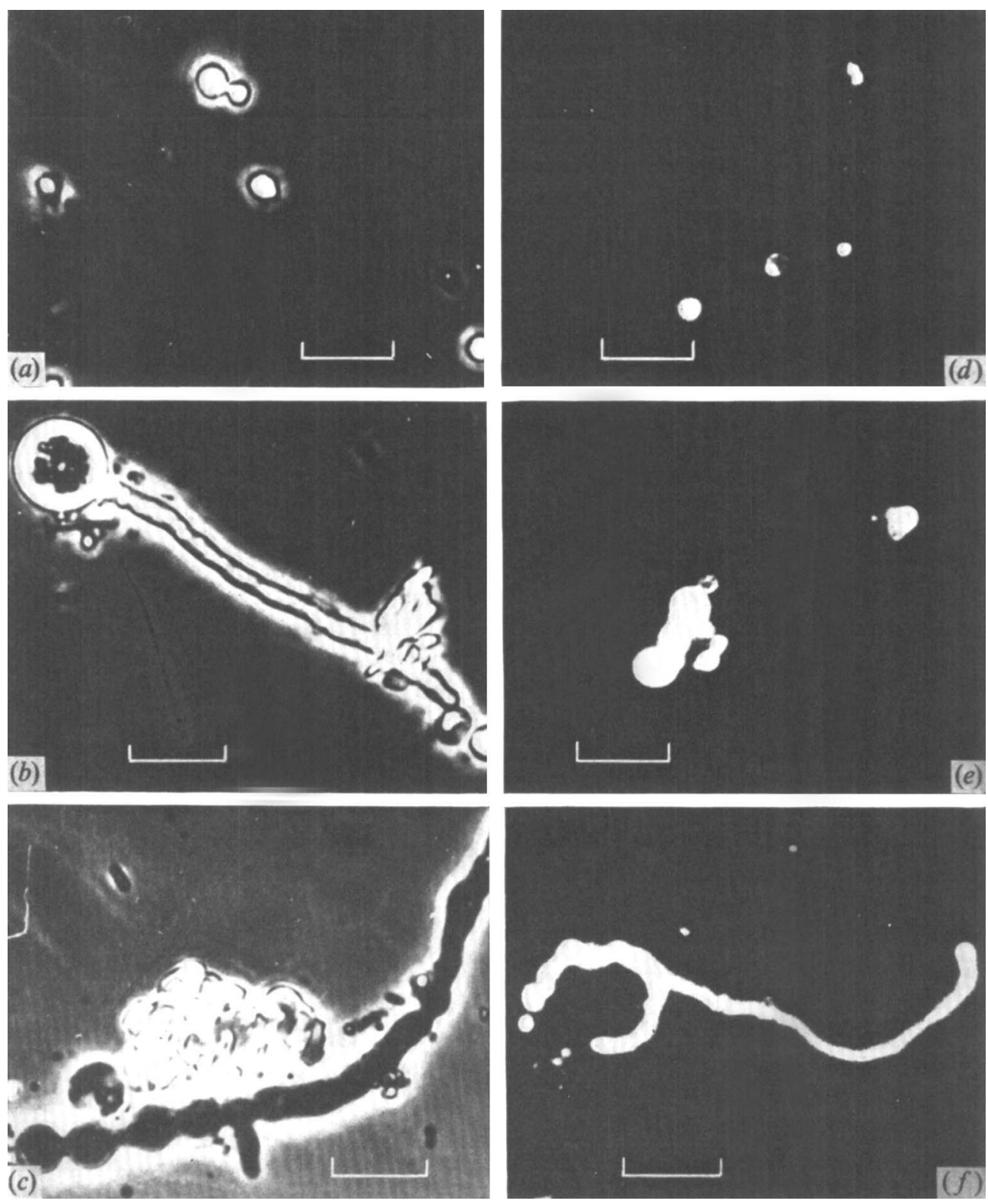

Fig. I. Regeneration of Pythium protoplasts shown with phase-contrast and fluorescence microscopy. Scale markers represent Io $\mu \mathrm{m}$. (a) Budding protoplasts after $2 \mathrm{~h}$ of regeneration. (b) Hypha developing from a protoplast after $8 \mathrm{~h}$ of regeneration. (c) Several swellings developed from one protoplast before a hypha is produced; after $8 \mathrm{~h}$ of regeneration. (d) Protoplasts of Pythium stained with Calcofluor after $\mathrm{I} h$. of regeneration. $(e)$ Same as $(d)$, after $4 \mathrm{~h}$ of regeneration. $(f)$ Same as $(d)$, after $8 \mathrm{~h}$ of regeneration. 
Table 2. Regeneration of Pythium protoplasts in liquid medium

Dry wt $(\mathrm{mg} / \mathrm{ml})$ after $24 \mathrm{~h}$ of regeneration of $10^{6}$ protoplasts $/ \mathrm{ml}^{*}$

Additions to the
regeneration medium
No additions
I $\%$ Glucose (gl)
$0.1 \%$ Asparagine (asp)
$0.1 \%$ Yeast extract (ye)
Gl+asp
Gl+ye
Gl+asp + ye

Additions to the

o additions

I $\%$ Glucose (gl)

$0.1 \%$ Yeast extract (ye)

Gl+asp

Gl asp + ye

$\begin{array}{cc}\begin{array}{c}\text { Osmotic stabilizer } \\ \mathrm{NaCl}(0.4 \mathrm{M})\end{array} & \begin{array}{c}\text { Osmotic stabilizer } \\ \text { mannitol }(0.65 \mathrm{M})\end{array} \\ 0.7 & 0.4 \\ 0.4 & \mathrm{I} \cdot 5 \\ 0.5 & 0.8 \\ 0.6 & 4.2 \\ 0.5 & 2.7 \\ 0.3 & 3.5 \\ 0.7 & 9.0\end{array}$

* Protoplasts $\left(10^{6} / \mathrm{ml}\right)$ were suspended in regeneration medium with the additions mentioned and incubated at $30^{\circ} \mathrm{C}$ in a shaking water bath. After $24 \mathrm{~h}$ the suspension was centrifuged $(3000 \mathrm{~g}$, I0 min) and the dry wt of the pellet was estimated.

surface of the agar. Gelatine could not be used as a solidifier since it was readily hydrolysed by Pythium.

Successful regeneration required the use of a suitable osmotic stabilizer. Inorganic salts, including $\mathrm{NaCl}, \mathrm{MgSO}_{4}, \mathrm{KCl}$ and $\mathrm{NH}_{4} \mathrm{Cl}$, completely inhibited regeneration, whereas organic compounds including sucrose, mannitol and sorbose did not inhibit this process.

The regeneration observed with these protoplasts that had been obtained from mycelium not older than $24 \mathrm{~h}$ was less than $\mathrm{I} 4 \%$, but protoplasts from older cultures (obtained by treating the mycelium with Triton $\mathrm{X}_{\mathrm{I}} 00$ ) regenerated more readily (up to $30 \%$ ).

In studies with liquid medium, glucose was essential for good regeneration. Nitrogen sources, including asparagine, yeast extract and peptone, were not necessary but stimulated the process of regeneration considerably (Table 2 ).

\section{DISCUSSION}

In a previous study it was shown that Pythium protoplasts could be obtained by incubating the mycelium with a combination of cellulase, exo- and endo- $\beta(\mathrm{I}-3)$ glucanase. Lipase was not essential but stimulated this process. The enzymes were obtained by growing a Streptomyces species on Pythium mycelium as carbon source (Sietsma et al. 1969).

In the present study we have found that protoplasts from Pythium mycelium could be obtained easily by incubating the mycelium with a combination of helicase and cellulase. Although helicase itself contained a considerable cellulase activity, addition of the Aspergillus niger cellulase stimulated protoplast formation further. This could have been because of differences in specificity of the cellulases, and chromatographic analysis of the products obtained by hydrolysing carboxy methyl cellulose (with helicase or A. niger cellulase) supports this conclusion.

The former enzyme complex appears to contain a cellulase with a more exo character and the latter one is a more endo type (J. H. Sietsma, unpublished data).

Although lipase activity was not detected in the Aspergillus niger cellulase preparation, it is possible that this enzyme preparation contains an unknown substance which promotes protoplast formation.

Triton X 100 considerably stimulated the formation of protoplasts and, as shown previously (Sietsma et al. I969), so does lipase. This suggests that the hyphal wall could be 
covered with a protective layer of lipid material. In contrast to this, the presence of an outer protein layer has been suggested for some other fungi and yeasts (Dooijewaard-Kloosterziel, Sietsma \& Wouters, I973). Protoplast formation in these species is not affected by the nature of the osmotic stabilizer (Villanueva \& García Acha, I97I ; Dooijewaard-Kloosterziel et al. I973), but is stimulated by SH-compounds and, in some cases, also by pronase (Duell, Inoue \& Utter, I964; Kovac, Bednarova \& Greksak, 1968; Bastide, Trave \& Bastide, 197I; Sommer \& Lewis, 197I ; Dooijewaard-Kloosterziel et al. 1973). These protective layers of proteinaceous or lipoid nature apparently change qualitatively or quantitatively or both as the organism grows older, since the ease with which protoplasts can be formed decreases progressively with mycelial age.

We have not been able to show unequivocally that the protoplasts formed in the way described in this paper entirely lack remnants of the hyphal wall. Several workers have shown that yeast protoplasts prepared with helicase still contain wall residues (Streiblova, I968; Bacon, Jones \& Ottolenghi, I969), although others claim to have made clean protoplasts by using this process (Fukui, Sagara, Yoshida \& Matsuoka, I969; Strunk, 1969). That the Pythium protoplasts lack most of the wall components is indicated by the absence of fluorescence after incubation with Calcofluor. Only after i h of regeneration could some fluorescence be seen (see also Peberdy \& Gibson, I97I). Necas (197I) reported regeneration of protoplasts of several yeast species only when they were embedded in a solid or semisolid medium. With Pythium no difference in regeneration efficiency was found when the protoplasts were either embedded in the agar or distributed over the surface.

The percentage of protoplasts able to regenerate is very low. The reason for this observation is not known yet, but a possibility is that only a small percentage of protoplasts contains one or more nuclei (García-Acha, López-Belmonte \& Villanueva, I966).

The use of the fluorescence microscope of the laboratory of Bacteriology of the University of Amsterdam is very much appreciated.

\section{REFERENCES}

Bacon, J. S. D., Jones, D. \& Ottolenghi, P. (I969). Cell wall residues in yeast protoplast preparations. Journal of Bacteriology 99, 885-896.

Bastide, J. M., Trave, P. D. \& Bastide, M. (I971). Élude de la paroi cellulaire de Candida macedoniensis: formation de protoplasts. Annales de l'Institut Pasteur I21, 31 1-324.

DoonewaArd-Kloosterziel, A. M. P., Sietsma, J. H. \& Wouters, J. T. M. (1973). Formation and regeneration of Geotrichum candidum protoplasts. Journal of General Microbiology 74, 205-209.

Duell, E. A., INoue, S. \& UTter, M. F. (1964). Isolation and properties of intact mitochondria from spheroplasts of yeast. Journal of Bacteriology 88, I $762-\mathrm{I} 773$.

Eveleigh, D. E., Sietsma, J. H. \& Haskins, R. H. (I968). The involvement of cellulase and laminaranase in the formation of Pythium protoplasts. Journal of General Microbiology 52, 89-97.

Fukui, K., Sagara, Y., Yoshida, N. \& Matsuoka, T. (1969). Analytical studies on regeneration of protoplasts of Geotrichum candidum by quantitative thin-layer agar plating. Journal of Bacteriology $\mathbf{9 8}$, $256-263$.

García-Acha, I., López-Belmonte, F. \& Villanueva, J. R. (1966). Regeneration of mycelial protoplasts of Fusarium culmorum. Journal of General Microbiology 45, 51 5-523.

Haskins, R. H. (1963). Morphology, nutrition and host range of a species of Pythium. Canadian Journal of Microbiology 9, 45I-460.

Kovac, L., Bednarova, H.\& Greksak, M.(I968). Isolation and properties of phosphorylating mitochondria from stationary phase cells. Biochimica et biophysica acta 153, 32-42.

NeCAS, O. (1971). Cell wall synthesis in yeast protoplasts. Bacteriological Reviews 35, 149-170.

Peberdy, J. F. \& Gibson, R. K. (I97I). Regeneration of Aspergillus nidulans protoplasts. Journal of General Microbiology 69, 325-330. 
PreECE, T. F. (I97I). Fluorescent techniques in Mycology. In Methods in Microbiology, vol. 4, pp. 509-5I6. Edited by C. Booth. London: Academic Press.

Sietsma, J. H., Eveleigh, D. E. \& Haskins, R. H. (1969). Cell wall composition and protoplast formation of some oomycete species. Biochimica et biophysica acta 184, 306-31 7.

Sietsma, J. H., Eveleigh, D. E., Haskins, R. H. \& SpenCer, J. T. F. (1967). 'Protoplasts' from Pythium sp. PRL 2142. Canadian Journal of Microbiology 13, I70I-I 705.

SOMmer, A. \& LeWIS, M. J. (197I). Effect of dithiothreitol on yeast; sphaeroplast formation and invertase release. Journal of General Microbiology 68, 327-335.

Streiblova, E. (1968). Surface studies of yeast protoplasts. Journal of Bacteriology 95, 700-719.

STRUNK, C. (I969). Licht und electronenmikroskopischen Untersuchungen an regenerierenden Protoplasten von Polystictus versicolor. Zeitschrift für allgemeine Mikrobiologie 9, 205-2 16.

Villanueva, J. R. \& García Acha, I. (I971). Production and use of fungal protoplasts. In Methods in Microbiology, vol. 4, pp. 665-7I8. Edited by C. Booth. London: Academic Press. 